\title{
Treatment with benznidazole in association with immunosuppressive drugs in mice chronically infected with Trypanosoma cruzi: investigation into the possible development of neoplasias
}

\author{
Tratamento com benzonidazol em associação com drogas imunossupressoras em \\ camundongos crônicamente infectados com Trypanosoma cruzi: investigação \\ sobre a possibilidade de desenvolvimento de neoplasias
}

Sonia G. Andrade1, Igor Marcelo Oliveira Mesquita ${ }^{12}$, Jamile F. Jambeiro ${ }^{12}$, Isis F. Magalhães Santos' ${ }^{1}$ and Renata Siqueira Portella'

\begin{abstract}
Benznidazole is recommended in Brazil for the treatment of Trypanosoma cruzi infection in acute and early chronic phases of Chagas' disease. Observations by others have indicated a higher incidence of neoplasias in immunosuppressed patients, presenting Chagas' disease reactivation, submitted to treatment with benznidazole. In the present study, we investigated whether there is a potentiation in the generation of lymphomas in chronically infected mice, treated with immunosuppressive drugs and benznidazole. For this, 142 Swiss mice chronically infected with the 21 SF strain of T. cruzi and 72 normal Swiss mice were used. Both infected and normal mice were divided into experimental groups and submitted to one of the following treatment regimens: benznidazole alone; immunosuppressive drugs (azathioprine, betamethasone and cyclosporin); a combination of immunosuppressive drugs and benznidazole; and untreated controls. In the infected group treated with benznidazole, one mouse developed a non-Hodgkin's lymphoma. This finding has been interpreted as a spontaneous tumor of mice. The study of the chronically infected mice treated with the combination of immunosuppressive drugs and benznidazole demonstrated an absence of lymphomas or other neoplasias. These findings support the indication of benznidazole, as the drug of choice, for immunosuppressed patients that develop a reactivation of Chagas' disease.
\end{abstract}

Key-words: Trypanosoma cruzi. Experimental infection. Chemotherapy. Benznidazole. Immunosuppressive drugs. Non-Hodgkin's lymphoma.

Resumo O benzonidazol é recomendado no Brasil para o tratamento da infecção pelo Trypanosoma cruzi na fase aguda e na fase crônica precoce da doença de Chagas. Observações de outros autores mostraram uma elevação na incidência de neoplasias em pacientes imunossuprimidos, com reativação da doença de Chagas, submetidos a tratamento com o benzonidazol. No presente estudo foi investigado em camundongos cronicamente infectados, tratados com drogas imunossupressoras e com benzonidazol se há uma potencialização de desenvolvimento de linfomas por esta combinação. Para isso foram usados 142 camundongos suiços crônicamente infectados pela cepa $21 S F$ do T.cruzi e 72 camundongos suiços normais. Tanto os camundongos infectados como os normais foram divididos em grupos experimentais submetidos respectivamente a diferentes esquemas de tratamento: com benzonidazol apenas; com drogas imunossupressoras (azatioprina, betametasona e ciclosporina); com drogas imunossupressoras mais benzonidazol; e controles não tratados. No grupo infectado e tratado com benzonidazol, um camundongo desenvolveu um linfoma não-Hodgkin. Este achado foi interpretado como um tumor espontâneo do camundongo. O estudo de camundongos crônicamente infectados e tratados com uma combinação de drogas imunossupressoras e benzonidazol demonstrou ausência de linfomas ou de outras neoplasias. Estes achados reforçam a indicação do tratamento com benzonidazol como droga de escolha em pacientes imunossuprimidos que desenvolvem reativação da doença de Chagas.

Palavras-chaves: Trypanosoma cruzi. Infecção experimental. Quimioterapia. Benzonidazol. Drogas imunossupressoras. Linfoma não Hodgkin.

\footnotetext{
1. Laboratório de Doença de Chagas Experimental do Centro de Pesquisas Gonçalo Moniz da Fundação Oswaldo Cruz, Salvador, BA..2. PIBIC da Fundação Oswaldo Cruz e Conselho Nacional de Pesquisa, Salvador, BA.

Address to: Dra. Sonia G. Andrade. Centro de Pesquisas Gonçalo Moniz/FIOCRUZ. Rua Waldemar Falcão 121, 40295-001 Salvador, BA, Brasil.

Recebido para publicação em 17/9/2002

Aceito em 18/5/2003
} 
Although the transmission of Chagas' disease in endemic areas has been successfully controlled ${ }^{12}$, patients with chronic infection, and new acute cases, due to different mechanisms of infection, necessitate chemotherapy treatment. As recently reviewed by Coura and Castro ${ }^{11}$, nitroimidazolyl benznidazole continues to be the drug in clinical use in Brazil, with an effective cure in early cases $^{3}$ and is recommended by the Fundação Nacional de Saúde ${ }^{14}$ Reactivation of Chagas' disease in immunosuppressed individuals, either due to AIDS $^{13181920}$ or to the use of immunosuppressive drugs in transplant patients ${ }^{1281721}$, has been reported. In such cases, chemotherapeutic treatment is mandatory and benznidazole is the drug generally used. However, clinical observations have shown an influence of treatment with benznidazole associated to immunosuppression upon the development of neoplasias, as described by Bocchi et $a l^{8}$. The latter treated patients with reactivation of $T$. cruzi infection, after cardiac transplantation and the use of immunosuppressive drugs. This fact has been confirmed by Almeida ${ }^{2}$ and Almeida et $a^{1}{ }^{1}$. These observations have implications, mainly related to the replacement of benznidazole by allopurinol ${ }^{12}$, the efficacy of which has not been established. Other authors ${ }^{18}$, on the contrary, succeeded in treating the reactivation of Chagas' disease using benznidazole, without reference to the development of neoplasias. In four heart-transplant patients, Stolf et $a^{R^{1}}$, detected 3 cases with reactivation of Chagas' disease. The treatment of these patients with benznidazole was successful and a follow-up of 160 to 500 days showed reversion of the acute manifestations, apparently with no detectable clinical or histological sequelae.

Since experimental observations by Teixeira et $a^{2324}$ regarding the presence of lymphomas in rabbits under treatment with nitroarenes ${ }^{24}$, and, specifically, benznidazole ${ }^{23}$ a controversy has been established. Clinical observations by Cançado ${ }^{9}$, and a recent review by Coura and Castro ${ }^{11}$, did not indicate an increased incidence of neoplasias in chagasic patients treated with benznidazole. Experimentally, treatment of the chronic phase of infection in mice with benznidazole, has never resulted in the development of neoplasias, either of the lymphoid organs or others, at least in our experience ${ }^{67}$.

With the objective of contributing to the clarification of whether there is in fact a potentiation of mutagenesis and lymphoma generation by the combined use of immunosuppressive drugs and benznidazole, an investigation was conducted with the experimental murine model of chronic T. cruzi infection using azathioprine, betamethasone and cyclosporin, in doses that could be compared with those used in transplant patients ${ }^{5}$.

\section{MATERIAL AND METHODS}

Experimental animals. A group of 178 Swiss mice, weighing 10 to $12 \mathrm{~g}$ were experimentally infected with the 21 SF strain of T. cruzi classified as biodeme Type II . Inoculation consisted of $4 \times 10^{3}$ trypomastigotes obtained from infected mouse blood. From this infected group, 142 mice that survived up to 100 days of infection, were divided into 4 groups of chronically infected mice as detailed below. For treatment control, 80 normal Swiss mice weighing 10 to $12 \mathrm{~g}$ were maintained until 100 days. Seventy two surviving mice were divided into 4 groups of uninfected controls. All the experimental mice were sacrificed at the end of treatment.

Parasitemia and cumulative mortality: were registered in the acute phase.

Experimental groups. Group 1: infected controls: 31 infected and untreated mice (Inf Co). Group 2: 31 infected mice treated with benznidazole (Inf Benz). Group 3: 40 infected mice treated with immunosuppressive combination: azathioprine (Imuran) + betamethasone (Celestone) + cyclosporin (Sandimun) (Inf IM). Group 4: 40 infected mice treated with immunosuppressive drugs followed by benznidazole (Inf IM Benz). Group 5: 25 uninfected control mice treated with immunosuppressive drugs (Co IM). Group 6: 14 uninfected control mice treated with benznidazole (Co Benz). Group 7: 14 uninfected control mice treated with immunosuppressive drugs and benznidazole (Co IM Benz). Group 8: 19 normal intact controls (No Co).

Schedules of immunosuppressive treatment. The surviving mice were in part, treated with the immunosuppressive drugs: azathioprine (Imuran), betamethasone (celestone) and cyclosporin (Sandimun), 100 days after infection. Doses and administration of the drugs were as follows: azathioprine, $10 \mathrm{mg} / \mathrm{kg}$ b.w. administered by gavage, 3 days a week for 4 weeks followed by one weekly dose for 90 days.

Betamethasone, $2 \mathrm{mg} / \mathrm{kg}$ b.w. administered intraperitoneally, 3 days a week, during 4 weeks and once a week during 90 days.

Cyclosporin, $30 \mathrm{mg} / \mathrm{kg}$ b.w., 3 days a week, by gavage, during 4 weeks, followed by a dose of $15 \mathrm{mg} /$ $\mathrm{kg}$ b.w. once a week for 90 days.

Chemotherapy treatment with benznidazole. Treatment with benznidazole (Rochagan) was initiated 4 weeks after beginning the immunosuppressive treatment. The drug was administered by gavage at a dose of $100 \mathrm{mg} / \mathrm{kg}$ b.w. day, for 5 days a week, during 90 days, concomitantly with the immunosuppressive treatment.

Group 1 (Inf Co) received sterile saline by gavage $(1 \mathrm{ml} /$ day $)$ during the same period of treatment.

Parasitaemia was checked before and after treatment. Cumulative mortality was evaluated at the pre-treatment phase until 100 days and during the treatment period for all groups, until 280 days. Mice from the various groups were evaluated according to the total number of leukocytes and the number of lymphocytes in peripheral blood, up to the end of the experiment.

White blood cell counts: blood collection was performed during the sacrifice of the mice, by sectioning 
the axillary plexus and collecting the blood with heparin into plastic vials, six weeks after the beginning of treatment (for treated animals) and at the same period for untreated controls. White blood cell counts were performed with an automatic Coulter count (T-890).

Statistical analysis: variance test was applied by using the Kruskal-Wallis method for comparing the number of leukocytes and lymphocytes in peripheral blood in normal controls and chronically infected mice from the experimental groups. Comparison was also performed for leukocytes and lymphocytes in chronically infected mice after immunosuppressive and or chemotherapy treatment. For evaluation of the significance of spleen indices in the several groups, the same test (variance test of Kruskal Wallis) was performed. Significance was post-tested by the Dunn's multiple comparison test.
Serology: serum antibodies were examined by indirect immunofluorescence (IIFT) using culture forms of T. cruzi as antigens and rabbit-anti- $T$. cruzi monospecific serum as primary antibody in dilutions of 1:10 until 1:640. As secondary antibody, a goat anti-rabbit lgG conjugated to fluorescein (Sigma) was used.

Histopathological study. Mice from the experimental groups, were sacrificed under anesthesia with ether, 30 days after the end of treatment. The blood was collected for white cell count and serological tests. Body weight and spleen weight were registered for each animal, and the relationship between spleen weight and body weight (spleen index) was determined. The various organs were fixed in Milloning formalin ${ }^{10}$ and paraffin embedded. Five micrometer thick $(5 \mathrm{~m})$ sections of the heart, skeletal muscle, liver, spleen and lymph nodes were stained with Hematoxylin and Eosin.

\section{RESULTS}

Parasitemia. Figure 1 shows the characteristic profile of the parasitemic curve of mice in the acute phase of infection with T. cruzi strain, biodeme Type II, with the highest peak at the $15^{\text {th }}$ day, and negativation in the chronic phase.
Cumulative mortality: the mortality rate was $15.2 \%$ in the pretreatment period, until 100 days post inoculation (Figure 2). After 100 days of infection, the indices of cumulative mortality varied according to the experimental groups, as shown in Figure 3 . The

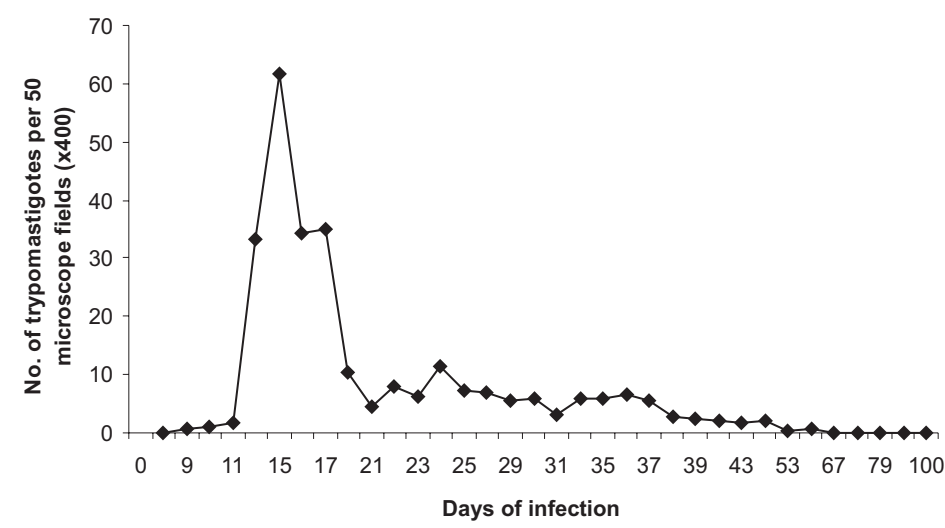

Figure 1 - Parasitemia levels in mice infected with the 21SF strain of Trypanosoma cruzi representing the acute phase and the chronic pre-treatment phase.

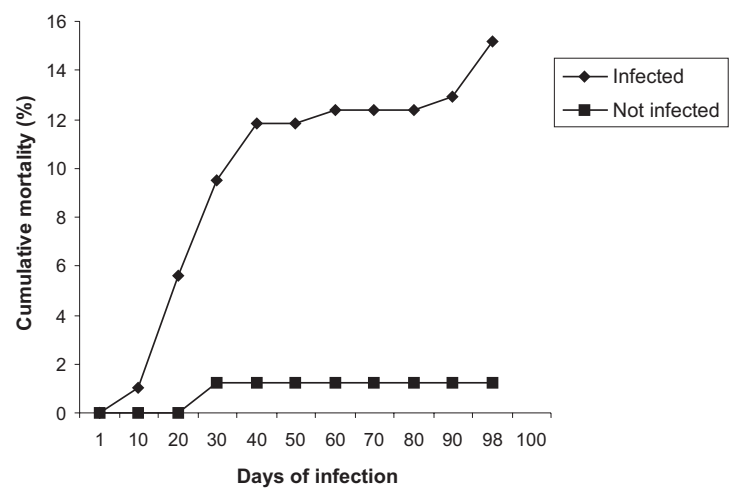

Figure 2 - Cumulative mortality of mice infected with Trypanosoma cruzi (21 SF strain) in the pre-treatment phase, as compared with normal controls. The mortality index was of $15,2 \%$ until 100 days post inoculation. 


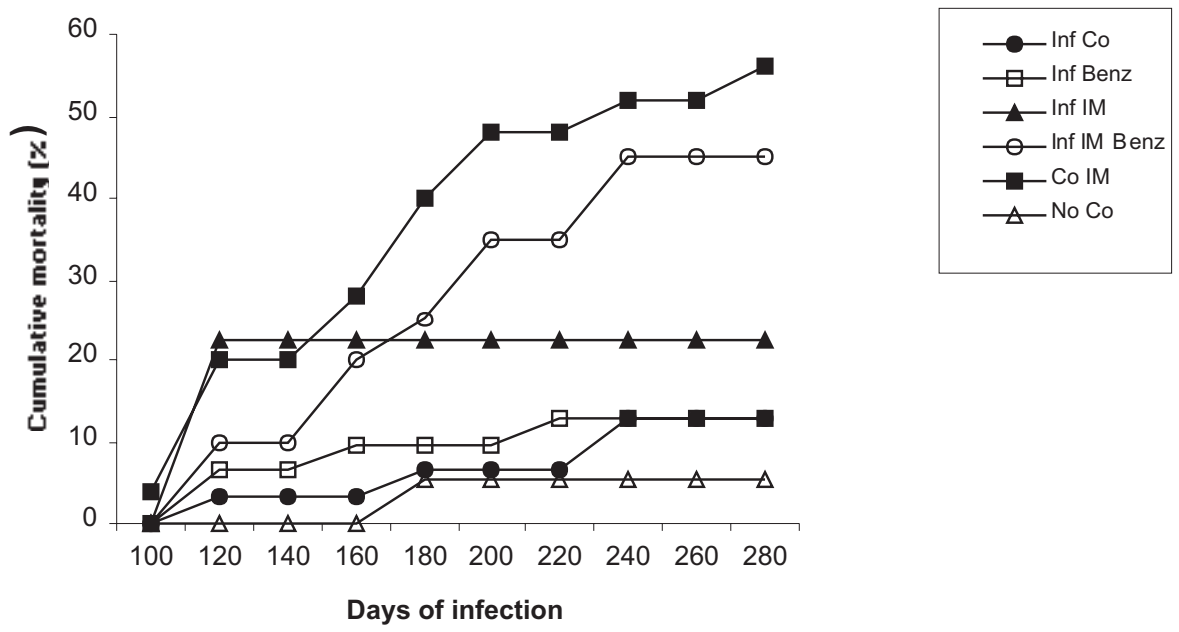

Figure 3 - Cumulative mortality of mice of different experimental groups: •-Inf Co; $\square$ Inf Benz; $\Delta$-In IM; O-Inf IM Benz; -Co IM; $\triangle$-No Co. The highest indices of mortality occurred in the groups of mice, infected and uninfected controls that have been treated with immunosuppressive drugs (Groups Inf IM, Inf IM Benz, Co IM), excluding group Co
$\mathrm{IM}$ Benz, with nule mortality (not included). Group 6 - Co Benz also showed nule mortality.

highest indices of mortality occurred in the groups of mice, both infected and uninfected controls that were treated with immunosuppressive drugs (Groups Inf IM, In IM Benz, Co IM), excluding Group Co IM Benz, with no mortality. Also the control group, treated with Benznidazole (Co Benz) presented zero mortality.

Histopathological study. General data: the heart of mice chronically infected with T. cruzi from Group 2 (In Benz) showed regression of the myocarditis, as compared with the infected controls (Inf Co), showing residual, focal inflammatory infiltrates limited to the atria, and focal areas of fibrosis of the myocardium. The other groups of infected mice: Inf Co, Inf IM, Inf IM Benz, presented either mild (+) or moderate (++) focal mononuclear infiltrates in the myocardium and skeletal muscle, with slight variation of intensity.

In several mice from the groups infected and treated with immunosuppressive drugs, pneumonia, pyelonephritis and pericarditis were present, as well as amyloid deposits in the spleen and liver.

Lymphoid tissue: in Group 2 (Inf Benz), out of 31 mice chronically infected and treated with benznidazole, one mouse presented neoplastic proliferation of lymphoid cells of the spleen, histologically characterized as a malignant non-Hodgkin's lymphoma (Figure 4-A, B, C and D). Infiltration with blastic lymphoid cells was present in the subepicardium and pericardiac lymph nodes, in the pulmonary tissue and in the sinusoidal and perivascular spaces of the liver (Figure 4-D). In this same group, the other animals showed either normal lymphoid organs or a mild $(+)$ to moderate $(++)$ hyperplasia of the lymphoid follicles of the spleen.

In the other infected groups, the spleen and lymph nodes revealed a normal structure in most of the cases, with mild (+) or moderate $(++)$ hyperplasia of lymphoid follicles.

Uninfected mice: in the animals of Group 5 (Co IM) the heart showed mild mononuclear infiltration and small focal areas of myocytolysis of heart. The spleen showed normal structure or atrophy of the lymphoid follicles in $50 \%$ of the cases and mild hyperplasia of the lymphoid follicles in the remaining $50 \%$. In the latter cases, amyloid deposits were present in the red pulp as well as in the liver. In the mice of Groups Co Benz, Co IM Benz and NoCo, no significant alterations were observed in the various organs.

Relationship between spleen weight and body weight (spleen index): Figure 5 shows the splenic indices for the several experimental groups. Case \#15 was not included (Group 2-Inf Benz), that developed a lymphoma and showed a significant increase in spleen weight (2.69g) in comparison with the mean weight of the spleen of the animals of the same group (0.39). Excluding this case, no significant statistical difference was detected between the spleen indices of the four infected groups and the intact controls. However a significant difference was observed between the spleen index of Group 1 (Inf Co) as compared with Group 7 (Co IM Benz) in which a significant decrease of spleen weight was detected ( $p<0.05)$.

White blood cells count. Results of the evaluation of the total number of leukocytes on infected and uninfected mice, treated or untreated, are shown in Figure 6. No significant statistical differences were detected between the infected groups in comparison with the intact controls. The mouse with a lymphoma (Group 2- Inf Benz) presented a higher number of 


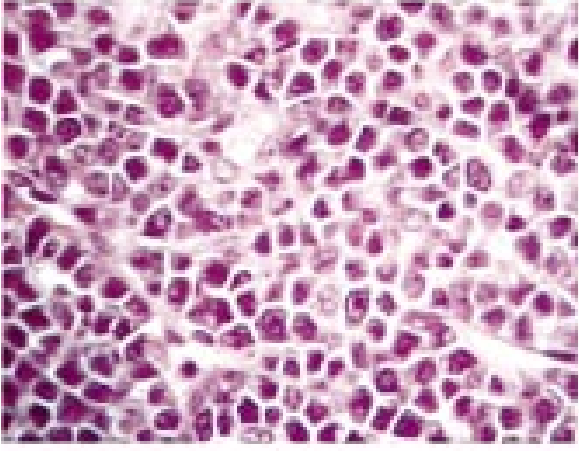

A

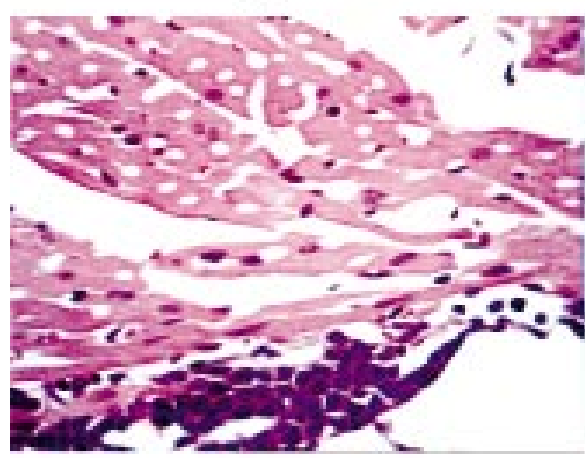

C

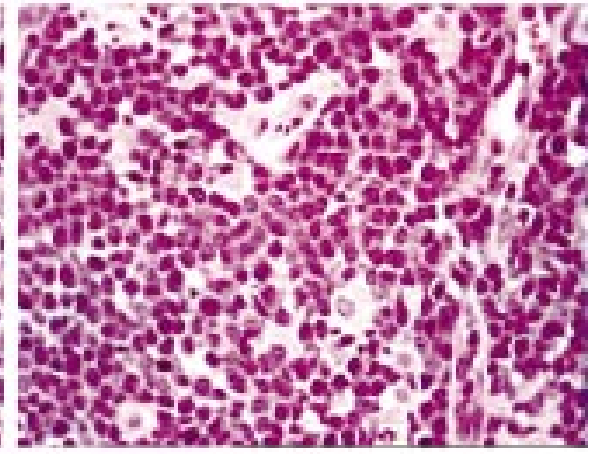

B

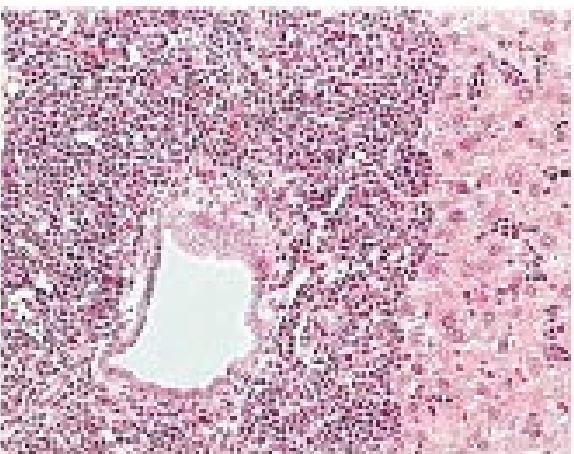

D

Figure 4 - Histopathological aspects: non-Hodgkin's lymphoma of the spleen: $\boldsymbol{A}$ - sections of the spleen showing neoplastic proliferation of small lymphoid cells, with irregular nuclei, with substitution of the follicular structure of the organ, $H \& E(400 X) ; B$ - sections of a lymph node with substitution of the follicular structure by blastic lymphoid cell proliferation, $H \& E(250 X)$. $\boldsymbol{C}$ - Heart section, with the presence of lymphoid blastic cells in the subepicardium. $H \& \dot{E}$ $(100 X)$. D - Invasion of the liver tissue by the neoplastic lymphoid cells. H\& E (200X).

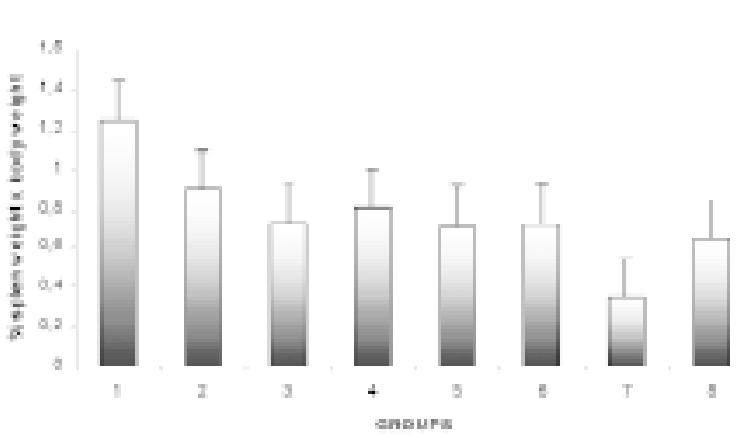

Figure 5 - Splenic indices of mice of the experimental groups infected with Trypanosoma cruzi and uninfected controls: 1-Inf Co; 2- Inf Benz; 3 - In IM; 4 -Inf IM Benz; 5 - Co IM; 6 - Co Benz; 7 - Co IM Benz; 8 - No Co. Highest spleen index was observed in Group 1 - In Co. No significant difference was detected by statistical analysis between the four infected groups and the normal controls (Group 8 - No Co). A significant difference was observed between the spleen index of Group 1 (Inf Co) compared
with Group 7 (Co IM Benz) in which a significant decrease of spleen weight was detected ( $\mathrm{p}<0.05$ ).

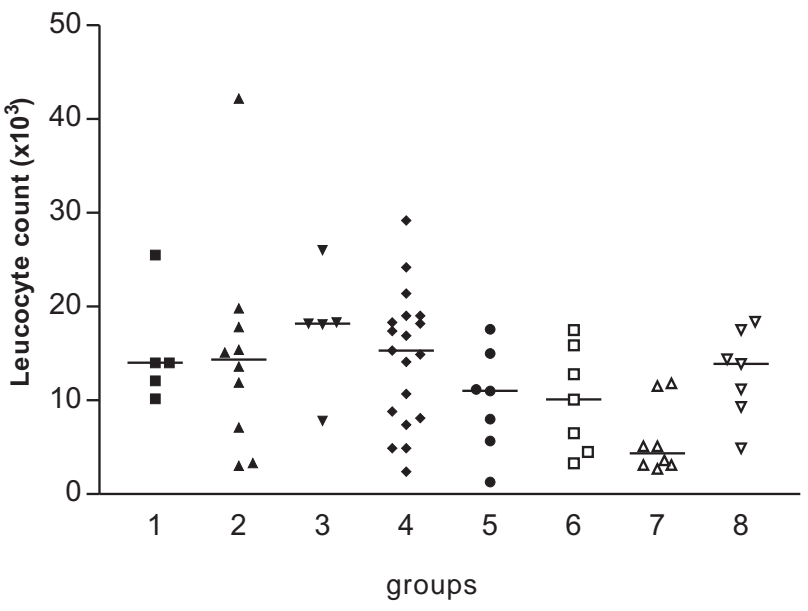

Figure 6 - Results of the evaluation of the total number of leukocytes in the peripheral blood of mice representative of the several experimental groups: 1 -Inf Co; 2 - Inf Benz; 3 - In IM; 4 -Inf IM Benz; 5 -Co IM; 6 -Co Benz; 7 - Co IM Benz; 8 - No Co. No significant statistical differences were detected between the infected groups in comparison with the intact controls. One mouse (*) of Group 2Inf Benz that presented a lymphoma of the spleen presented a
higher number of leukocytes. Significant decrease of the total higher number of leukocytes. Significant decrease of the total Benz) as compared with Groups 3 (Inf IM) and 4 (Inf IM Benz). 
lymphocytes $\left(47.7 \times 10^{3}\right)$ in comparison with the other mice of the same group. A significant decrease in the total number of leukocytes was seen in Group 7 (Co IM Benz) as compared with Groups 3 (Inf IM) and 4 (Inf IM Benz). The number of lymphocytes, showed slight variations between the several groups, excluded the mice with lymphoma (Case \#15). A statistically significant difference $(P<0.05)$ (Figure 7$)$, was detected between Group 4 (Inf IM Benz) and Group 7 (Co IM Benz).

Serological test (IIFT): Table 1 shows the variation of titers of the IIFT in the several groups. A decrease in the titers occurred in Group 2 (Inf Benz) and varied from 1/40 to $1 / 640$; the other infected groups maintained the serological titers. All uninfected control mice were negative.

Table 1 - Variation of the titers of IIFT in the infected mice of Groups 1 to 4.

\begin{tabular}{lrr}
\hline & \multicolumn{2}{c}{ Variation in titers } \\
\cline { 2 - 3 } Infected Groups & Minimum & Maximum \\
\hline Group 1 & $1: 320$ & $1: 1280$ \\
Group 2 & $1: 40$ & $1: 640$ \\
Group 3 & $1: 320$ & $1: 640$ \\
Group 4 & $1: 40$ & $1: 320$ \\
\hline
\end{tabular}

*Uninfected controls: negative results in the 4 groups

Groups:1 - Inf Co; 2 - Inf Benz; 3 - Inf Im; 4 - Inf IM Benz

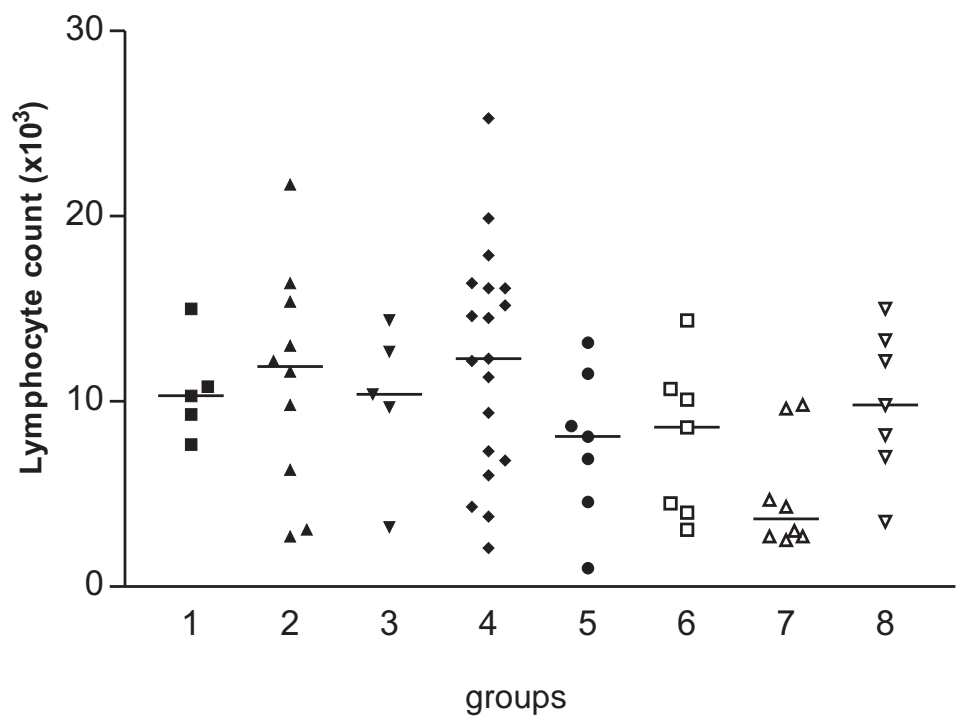

Figure 7 - Evaluation of the number of lymphocytes in the experimental groups: 1-Inf Co;2-Inf Benz; 3 - In IM; 4 -Inf IM Benz; 5 - Co IM; 6 - Co Benz; 7 - Co IM' Benz; 8 - No Co. The number of lymphocytes, showed slight variations between the groups. One mouse (*) of group 2 (Inf Benz) with lymphoma, presented a higher number of lymphocytes. A statistically
significant difference $(\mathrm{P}<0.05)$ was detected between Group 4 (Inf IM Benz) and Group 7 (Co IM Benz).

\section{DISCUSSION}

The results indicate that the association of benznidazole with immunosuppressive drugs did not contribute to the appearance of lymphomas or other neoplasias in mice chronically infected with T. cruzi. In a previous study ${ }^{5}$ done with Swiss mice chronically infected with different strains of T. cruzi, and submitted to immunosuppressive treatment, but not treated with benznidazole, none developed neoplastic proliferation of lymphoid tissues. In the control group of normal mice, the immunosuppressive treatment combined with benznidazole caused a significant decrease in the number of leukocytes and lymphocytes in peripheral blood and of the spleen index that indicate a response of the lymphoid organs to this type of treatment. However, the infected mice submitted to the same regimens, did not show this type of response. This appears to indicate that the infected mice maintained their leukocyte response, even under the influence of immunosuppressive drugs or benznidazole treatment, with mild to moderate hyperplasia of lymphoid follicles, without proliferation of the cells of the germinal centers.

In the present study a non-Hodgkin's lymphoma of the spleen and lymph nodes was detected in one mouse of the group treated exclusively with benznidazole. The finding of one case of non-Hodgkin's lymphoma out of 31 chronically infected mice treated with chemotherapy (3.2\%), could not be considered a priori as evidence of a direct action of the nitroimidazolyl on its development. Spontaneous lymphoma in mice has been registered not only in 
some inbred strains most susceptible to the development of such tumors as in outbred strains of mice currently used in laboratories, as reported by Furmanski and Rich ${ }^{15}$. According to these authors leukemia and other hematological malignancy in mice are estimated to have a spontaneous incidence of 1 to $2 \%$. Many highly inbred strains of mice can be selected with a high incidence of these types of neoplasias, for example the SLJ ${ }^{1622}$. Considering the Swiss mice, Furmanski and Rich $^{15}$, registered the results of different authors with a variation from 1 to $22.8 \%$ in the incidence of spontaneous lymphomas.
The present investigation contributed to demonstrating that the combined use of immunosuppressive drugs with benznidazole, in doses that mimic the treatment of transplant patients, did not effectively determine the appearance of lymphomas in Swiss outbred mice strain. These have proven not to be refractory to the spontaneous development of this type of tumor as presently demonstrated. Our findings support the indication of treatment with benznidazole for immunosuppressed patients that develop reactivation of $T$. cruzi infection.

\section{REFERENCES}

1. Almeida DR. Transplante cardíaco no tratamento da miocardiopatia chagásica. (Resumo de Tese) Revista da Sociedade Brasileira de Medicina Tropical 30:425-427, 1997.

2. Almeida DR, Carvalho AC, Branco JN, Pereira AP, Correa L, Vian Buffolo E, Martinez EE. Chagas' disease reactivation after heart transplantation: efficacy of allopurinol treatment. Journal of Heart Lung Transplantation 15:998-992, 1996.

3. Andrade AL, Zicker F, de Oliveira RM, Almeida Silva S, Luquetti A, Travassos LR, Almeida IC, de Andrade SS, de Andrade JG, Martelli $\mathrm{CM}$. Randomised trial of efficacy of Benznidazole in treatment of early Trypanosoma cruzi infection. Lancet 348:1407-1413, 1996.

4. Andrade SG. Caracterização de cepas do Trypanosoma cruzi isoladas no Reconcavo Bahiano. Revista Patologia Tropical 3:65-121, 1974.

5. Andrade SG, Carneiro Filho A, Maia de Souza AJ, Lima ES, Andrade ZA. Influence of treatment with immunosuppressive drugs in mice chronically infected with Trypanosoma cruzi. International Journal of Experimental Pathology 78:391-399, 1997.

6. Andrade SG, Magalhães JB, Pontes AL. Evaluation of chemotherapy with Benznidazole and Nifurtimox in mice infected with Trypanosoma cruzi strains of different types. Bulletin of the World Health Organization 63: 721-726, 1985.

7. Andrade SG, Magalhães JB, Pontes AL. Terapêutica da fase crônica da infecção experimental pelo Trypanosoma cruzi com Benzonidazol e Nifurtimox. Revista da Sociedade Brasileira de Medicina Tropical 22:113-118, 1989.

8. Bocchi EA, Bellotti VIP, Kalil J, Higuchi ML, Fiorelli A, Stolf N, Jatene A, Pilleggi $F$. Long-term follow up after heart transplantation in Chagas' disease. Transplantation Proceedings 25:1329-1330,1993.

9. Cançado JR. Tratamento específico In: Cançado JR, Chuster M (eds) Cardiopatia Chagásica, $1^{\text {a }}$ edição, Fundação Carlos Chagas de Pesquisa Médica, p.327-355, 1985.

10. Carson FL, Martin JH, Lyn JA. Formalin fixation for electron microscopy a re-evaluation. American Journal of Clinical Pathology 59:365-373,1973

11. Coura JR, Castro SL. A critical review on Chagas disease chemotherapy. Memórias do Instituto Oswaldo Cruz 97:3-24,2002.

12. Dias JCP, Coura JR. Epidemiologia. In: Dias JCP, Coura JR (eds) Clínica e Terapêutica da Doença de Chagas: Uma Abordagem Prática para o Clínico Geral, FIOCRUZ, Rio de Janeiro-p. 36-66, 1997.

13. Ferreira MS, Nishioka Sde A, Rocha A, Silva AM, Ferreira RG, Oliver W, Tostes Junior S. Acute fatal Trypanosoma cruzi meningoencephalitis in a woman immunodeficiency virus-positive hemophiliac patient. American Journal of Tropical Medicine and Hygiene 45:723-727, 1991.

14. Fragata Filho AA, Luquetti $A O$, Prata A, Rassi A, Gontijo ED, Ferreira HO, Cançado JR, Coura JR, Andrade SG, Macedo V, Amato Neto VA, Oliveira Jr W, Brener Z. Etiological treatment of Chagas Disease (The National Health Foundation of Brazil). Parasitology Today 13:127-128, 1997.

15. Furmanski P, Rich MA. Neoplasms of the hematopoietic system. In The Mouse in Biomedical Research. Vol.4, Eds. Academic Press Inc, 1982.

16. Hiai H. Genetic predisposition to lymphomas in mice. Pathology International 46: 707-718, 1996.

17. Libow LF, Beltrani VP, Silvers DN, Grossman ME. Post-cardiac transplant reactivation of Chagas' disease diagnosed by skin biopsy. Cutis 48: 37-40, 1991.

18. Nishioka AS, Ferreira MS, Rocha A, Burgarelli MKN, Silva AM, Duarte MIS, Schmitt FC. Reactivation of Chagas' disease successfully treated with Benznidazole in a patient with acquired immunodeficiency syndrome. Memórias do Instituto Oswaldo Cruz 88:493-496, 1993.

19. Rocha A, de Menezes AC, da Silva AM, Ferreira MS, Nishioka SA, Burgarelli MK, Almeida E, Turcato Júnior G, Metze K, Lopes ER. Pathology of patients with Chagas' disease and acquired immunodeficiency syndrome. American Journal of Tropical Medicine and Hygiene 50:261-268, 1994.

20. Rosemberg S, Chaves CJ, Higuchi ML, Lopes MBS, Castro LHM, Machado LR. Fatal meningoencephalitis caused by reactivation of Trypanosoma cruzi infection in a patient with AIDS. Neurology 42: 640-642, 1991.

21. Stolf NA, Higushi L, Bocchi E, Bellotti G, Auler JO, Uip D, Amato Neto V, Pileggi F, Jatene AD. Heart transplantation in patient with Chagas' disease cardiomyopathy. Journal Heart Transplant 6:307-312, 1987.

22. Tang JCO, Ho FCS, Chan ACL, Srivastava G. Clonality of lymphomas at multiple sites in SJL mice. Laboratory Investigation 78:205-212, 1998.

23. Teixeira ARL, Cordoba JC, Souto Maior I, Solórzano E. Chagas' disease: lymphoma growth in rabbits treated with Benznidazole. American Journal of Tropical Medicine and Hygiene 43:156158, 1998.

24. Teixeira ARL, Silva R. Cunha Neto E, Santana JM, Rizzo LM Malignant non-Hodgkin's Iymphoma in Trypanosoma cruzi infected rabbits treated with nitroarenes. Journal of Comparative Pathology 103:37-48, 1998. 